\title{
Analysis of Financial Performance and Firm Size on Level of Profit Sharing for Mudharabah Deposits
}

\author{
Putri Dwi Wahyuni \\ \{putri.dwi@mercubuana.ac.id\} \\ Universitas Mercu Buana, Indonesia
}

\begin{abstract}
This study aims to Analysis of Financial Performance and Firm Size on Level of Profit Sharing for Mudharabah Deposits. Independent variables used in the study, such as Return On Assets (ROA), The cost-revenue ratio (BOPO), Capital Adequacy Ratio (CAR) and Firm Size. This study used a sample of Islamic Banks registered with Bank Indonesia and the Financial Services Authority 2012-2017 period. Data were collected using purposive sampling technique. The analytical method used is the multiple regression analysis. Based on the results of multiple linear regression analysis, the results of this study indicate that ROA and BOPO no effect on the profit sharing rate of mudharabah deposits. While the CAR dan Size effect on the on the profit sharing rate of mudharabah deposits.
\end{abstract}

Keywords: Islamic Bank, Level Sharing Mudharabah Deposits, ROA, BOPO, CAR, Size.

\section{Introduction}

Islamic global economic growth continued to experience rapid growth. This is evidenced by the start the number of countries that use the Islamic economic system. The development of Islamic finance in Indonesia has resulted in a wide range of achievements, from the increasing number of products and services to the infrastructure that supports the development of Islamic finance. In the global market, Indonesia is included in ten of the country which has the world's largest Islamic finance. According to data of the Global Islamic Economic Indicator 2017, Indonesia was in position 10. The development of Islamic economy continued to improve in its growth. Currently Indonesia is ranked 9th in the world category total assets of Islamic finance, is still far below neighbouring Malaysia which is located in the 3rd position (Figure 1. Thomson Reuters Islamic Finance Development Report 2016). Rapid growth of Islamic banks in Indonesia are also not yet in line with the understanding and knowledge of the public about Sharia banking operational system. Although Islamic banks continues to grow each year, many people still don't know that Indonesia what and how its business activities run Sharia banks (Saddiyah, 2018) (1).

The growth in Islamic finance has not been able to offset the conventional financial growth. It can be seen from the market share the Islamic finance as a whole are still below 5\%. But if the views of each product type, to the end of December 2016, there are several Islamic products his market share above 5\%, among other Islamic banking assets amounted to 5.33\% of all banking assets, state sukuk which reached $14.82 \%$ of the total outstanding state securities, the institution of Islamic financing amounting to $7.24 \%$ of total financing, special Islamic financial services institutions of $9.93 \%$ and Islamic microfinance institutions of 
22.26\%. Meanwhile, Islamic products that its market share was still below 5\%, among other corporate sukuk in circulation of $3.99 \%$ of the value of corporate bonds and sukuk, Shariahcompliant mutual funds net assets amounted to $4.40 \%$ of the total net asset value of mutual funds and Islamic insurance amounted to $3.44 \%$. In addition to the above financial products, stock issuers and public companies that meet the criteria as Shariah-compliant stocks reach $55.13 \%$ of the market capitalization of stocks listed on the Indonesia stock exchange. The figures above show that Islamic finance Indonesia still needs to continue to be developed so as to offset the conventional financial growth in order to raise the finance industry as a whole (www.ojk.go.id).(2)

Based on Article 1 of Law no. 21 of 2008 Islamic Bank is a Bank that runs its business activities based on sharia principles and according to its kind consisting of Islamic General Bank and Islamic people's Bank Financing. Islamic Bank is the bank that its activities refers to Islamic law and in its activities do not charge interest or not pay interest to customers. The rewards received by Islamic banks as well as paid to the customer depending on the contract and agreement between customer and the bank. Agreement in Islamic banking should be subject to the terms and the tenets of the contract as provided for in Islamic Shari (Ismail, 2016, p. 25).

Funding products in Islamic banking can take the form of demand deposits, savings and time deposits. One of the many interested fund products is deposits mudharabah, where Islamic banks acted as mudarib (fund managers) while customers acts as shahibul maal (owner of funds) in his capacity as mudharib. Islamic banks can conduct various types of businesses that are not contrary to Islamic principles as well as expanding it. Islamic banks will share the results to the owners of the funds or the owner of the deposit in accordance with the agreed ratio and that has been pstated in the contract..

Financial performance that are used in this research include: Return On Assets (ROA), the cost revenue ratio (BOPO) and Capital Adequacy Ratio (CAR). ROA is a ratio that describes the ability of the banks to manage he funds invested in the overall asset that produces profits. BOPO is a ratio that indicates the level of efficiency of the bank's operational performance. CAR is a capital adequacy ratio that must be provided to ensure the funds depositors. The goal is to make the liquidity or the ability of the banks to pay depositors fairly assured. Capital is one of the important factors in developing a business and accommodating the risk of loss, the higher the CAR, the stronger the bank's ability to bear the risk of any risky credit or productive assets.

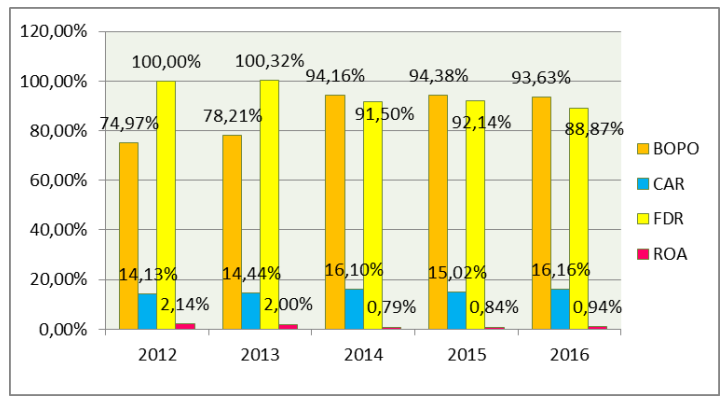

Fig. 1. Ratio of Islamic Banking in Indonesia Source Data : Otoritas Jasa Keuangan (OJK), data processed (2) 
Financial ratios such as BOPO, CAR, FDR increased relatively in 2013, except for profitability ratio or ROA which decreased from $2.00 \%$ in 2013 to $0.79 \%$ in 2014 . This occurred because of an increase in reserve costs and operating income that does not grow significantly. The Chairman of the Business Development Association of the Indonesian Islamic Bank (Asbisindo), Dinno Indiano said that the growth of the Islamic banking micro business was stagnant in 2013-2014 and until now the growth of Islamic banking industry lending had only reached a single digit. Bank capital is requested by Bank Indonesia to maintain a minimum capital adequacy requirement of $8 \%$. Assessment is at the Capital Adequacy Ratio (CAR) with a minimum of $8 \%$. Capital Adequacy Ratio (CAR) is a ratio that shows how much total bank assets that contain risk (credit, inclusion, securities, claims to other banks) are financed from own capital in addition to obtaining funds from sources outside the bank (Akbar, 2018) (3). The performance of Islamic banking fund raising has been growing. The high growth in deposits was DPK driven by the increasingly competitive convenience for the results to offer by Islamic banking, although in general the conventional bank deposits interest rates tend to increase its cost with improved performance, however, Islamic banks can provide convenience for high results (www.bi.go.id). This is shown in the following graph:

Several studies have been conducted regarding the company performance and interest rates on the level of profit sharing of mudharabah deposits as follows: according to Isna \& Sunaryo (2012), ROA and CAR have a positive and significant effect on the level of profit sharing of mudharabah deposits while BOPO has no effect on profit sharing of mudharabah deposits (4). Rahmawaty \& Yudina (2015) show the results that Return on Assets (ROA) does not affect the level of profit sharing of mudharabah deposits (5), while the research of Nofianti, et al (2015) and Rahayu \& Bustamam (2016) shows that ROA has a significant positive effect on profit sharing mudharabah deposits while BOPO does not have a significant effect on the level of Depsito mudharabah profit sharing (6),(7). Nur \& Nasir's (2014) research shows that BOPO has a negative and significant effect on the level of profit sharing of mudharabah deposits, whereas a research by Literal, et al (2016) shows that BOPO has a significant positive effect on the level of profit sharing of mudharabah deposits. Based on the phenomena and problems described previously, the objectives of this study include 1) to analyze the effect of ROA on the level of mudharabah deposits, 2) to analyze the influence of BOPO on the level of profit sharing of mudharabah deposits, 3) to analyze the effect of CAR on the level of the results of mudharabah deposits and 4) to analyze the effect of company size on the level of profit sharing of mudharabah deposits.

\section{Literature review}

\subsection{Agency Theory}

Jensen \& Meckling (1976) defines the Agency theory as the relationship between agents (management) and Principals (company owners) that are bound in a contractual (8). The Principal assigns tasks to the agents to provide services for the interest of the principal. Agency theory or also in the literature called "contracting theory" is a theory sources from the company's theory raised by Coase (1937). In this study the principal is called a depositor or owner of the fund with his agent, the relevant Islamic General Bank. This agency relationship is created when depositors entrust their money to be managed by the related BUS. For this 
reason, management must provide accurate financial reporting and disclosure of the performance of the BUS to the principal (depositor) because there will be differences in information received by the depositor and Islamic General Bank to minimize the occurrence of information asymmetry (9).

\subsection{Islamic Bank}

Decree of Bank Indonesia Director No. 32/148 / KEP / DIR dated 12 November 1998 article 12 paragraph (3) states that a Bank based on Islamic principles is a bank operating under Sharia principles. Islamic banking moves using a system based on Islamic economics Islamic banking as a financial institution applies Islamic principles, including the following:

1. Prohibition of applying interest to all forms and types of transactions

2. Run a business activityn and trade is based on fairness and halal profit

3. Removing zakat from the results of its activities

4. Prohibition of monopoly

5. Working together in building society, through business activity and trade that are not prohibited by Islam. The five Islamic principles are a reference for Islamic banking institutions in carrying out their business activities.

\subsection{Financial Performance}

1. Return On Asset (ROA)

Return on Assets (ROA) is a ratio used to measure the ability of managing the bank in obtaining profits as a whole reached the bank and also the better position of the bank in terms of asset use (Sholihin, 2013, p.724).

2. Capital Adequacy Ratio (CAR)

CAR is a capital adequacy ratio that must be provided to guarantee depositors' funds. The aim is to ensure that the liquidity or ability of banks to pay depositors is sufficient.

3. The Cost-Revenue Ratio (BOPO)

BOPO is a ratio to measure the level of efficiency and ability of the bank in conducting its business.

4. Firm Size

Firm size is one indicator used by investors in assessing assets and company performance. The size of a company can be seen from the total assets, net sales owned by the company (Sudarmadji \& Sularto, 2007).

\subsection{Level of Profit Sharing for Mudharabah Deposits}

Profit sharing is the distribution of the results of the business carried out by the parties making the agreement, namely the customer and the Islamic bank. Distribution of business results in Islamic banking is determined by using a ratio. Ratio is the percentage agreed upon by both parties in determining the profit sharing or business cooperated (Ismail, 2011, p.75). Revenue sharing will differ depending on the basis of the calculation of profit sharing, namely the profit 
sharing calculated using the concept of profit / loss sharing and profit sharing by using revenue sharing.

1. Profit / loss sharing is a calculation of profit sharing based on the net result of total revenue after deducting the costs incurred to obtain the income.

2. Revenue Sharing is a calculation of profit sharing based on the total of all income received before deducting costs incurred (10).

Based on PSAK 105 (IAI, 2009) states that mudharabah is the contract between two parties where the first party (owner of capital) provides all capital, while the second party (manager capital) acts as manager and profits will be divided according to the agreement whereas if there is a loss, then the loss is borne entirely by the owner of the capital provided that there is no mistake or fraud committed by mudharib or the manager. Deposits with the principle of mudharabah are types of investments in banks in rupiah and foreign currencies whose withdrawals can only be made at the time the deposit is due (according to the time period).

In the Statement of Financial Accounting Standards (SFAS) No. 105 of 2007 concerning Mudharabah Accounting, mudaraba characteristics as follows:

1. The entity can act either as a fund owner or fund manager.

2. Mudharabah consists of mudharabah muthlaqah, mudharabah muqayyadah, and mudharabah musyrakah. If the entity acts as a fund manager, the funds received are presented as temporary syirkah funds.

3. In mudharabah muqayyadah, examples of limitations include:

a. Do not mix fund owner funds with other funds.

b. Do not invest funds in installment sales transactions, without guarantors, or without collateral.

c. Require fund managers (mudharib) to invest themselves without going through third parties.

4. In principle, in the distribution of mudaraba there is no guarantee, but in order for the fund manager (mudharib) not to make a deviation, the owner of the fund can request a guarantee from the fund manager (mudharib) or a third party. This guarantee can only be disbursed if the fund manager (mudharib) is proven to have committed a violation of the things agreed upon in the contract.

5. Mudharabah refunds can be made in stages together with the profit sharing distribution or in total when the mudharabah agreement is terminated.

6. If the management of the mudharabah fund generates profits, then the portion of the profit sharing amount for the fund owner and fund manager (mudharib) is determined based on the agreed ratio of the results of the business obtained during the contract period. If the management of a mudharabah fund causes a loss, then the financial loss is borne by the fund owner.

\subsection{Previous Research}

According to Isna \& Sunaryo (2012) states that ROA and BOPO have a significant effect on the level of profit sharing of mudharabah deposits (4). Anisah et al. (2013), Andriyanti \& Wasilah (2010) and Setyawati, et al (2016) say that bank size has a significant positive effect on mudharabah savings in Islamic banks in Indonesia. Whereas Rachman et al. (2013) shows that bank size has a significant and no positive effect on mudharabah savings in Islamic banks in Indonesia. Umiyati \& Syarif (2016) show that ROA and CAR that have a significant influence on the level of profit sharing of mudharabah deposits while BOPO does not have a 
significant effect on the level of profit sharing of mudharabah deposits (11). According to Harfiah et al (2016) stated that ROA and BOPO have a significant effect on the level of profit sharing of mudharabah deposits. While the research of Juliana \& Mulazid (2017) states that CAR does not affect mudharabah savings.

\section{Research Model, Hypothesis and Methodology}

\subsection{Research Model}

This research uses a quantitative approach with a model of experimental research is research that aims to test the hypothesis of a causal effect. In this study researchers tried to see the effects of the independent variables on the dependent variable (12). The independent variables in this study include ROA, BOPO, CAR and Firm Size while the dependent variable is the level of profit sharing of mudharabah deposits. Following is the model of this research which can be seen in Figure 4.

\subsection{Hypothesis}

Effect of ROA on Level of Profit Sharing for Mudharabah Deposits

Based on agency theory, Islamic General Banks are able to manage the funds invested in all assets that will generate income, so that the level of profit sharing provided to the principal also increases. The results of research conducted by Umiyati \& Syarif (2016) show that Return on Assets (ROA) is the most dominant variable on the level of profit sharing of mudharabah deposits (11). With a high value of ROA, the level of profit sharing of mudharabah to be received will also be higher. Based on the description above, the first hypothesis that will be tested in this study is

H1 = Return On Asset affects the level of profit sharing of mudharabah deposits

Effect of the Cost-Revenue Ratio (BOPO) on Level of Profit Sharing for Mudharabah Deposits

Based on agency theory, agency relations occur when agent (management) and principals (the company owners) that are bound in a contractual. The Principal assigns tasks to agents to provide services for the benefit of the principal. In order to avoid agency conflicts and avoid high operational costs. IslamicGeneral Banks (agents) must be more selective in financing operational costs in order to obtain high income. According to (Isna \& Sunaryo 2012) the BOPO value decreases if the operational costs decrease on the other hand the operating income is fixed, and also if the operational costs remain on the other hand the operating income increases (4). With the value of the cost-revenue ratio (BOPO) getting lower, the level of profit sharing of mudharabah deposits received by customers is higher. Based on the description above, then the second hypothesis that will be tested in this study is

$\mathrm{H} 2$ = the Cost-Revenue Ratio (BOPO) affects the profit sharing of mudharabah deposits

Effect of CAR on Level of Profit Sharing for Mudharabah Deposits

Based on agency theory, Islamic General Banks are responsible for maintaining capital and controlling risks that arise and affect the amount of capital. Because capital is one of the 
important factors in order to accommodate the risk of losses. Research by Umiyati \& Syarif (2016) which states that CAR partially influences the level of profit sharing of mudharabah deposits (11). If a Sharia Commercial Bank can maintain capital and control the risks that will arise, the trust of the public and customers to the Sharia Commercial Banks will increase so that it influences the collection of funds used for operational purposes. Based on the description above, then the third hypothesis that will be tested in this study is

H3 = Capital Adequacy Ratio affects the profit sharing of mudharabah deposits

Effect of Firm Size on Level of Profit Sharing for Mudharabah Deposits

Based on the agency theory of company size seen from the size of total assets can create an agency relationship between the owner of the fund (Shahibul Maal) and the Islamic Commercial Bank (agent) so that the Sharia Commercial Bank (mudharib) is believed to be able to manage the funds owned by Shahibul Maal. Anisah et al. (2013), Andriyanti \& Wasilah (2010) and Setyawati, et al (2016) say that bank size has a significant positive effect on mudharabah savings in Islamic banks in Indonesia. Based on the description above, then the fourth hypothesis that will be tested in this study is

$\mathrm{H} 4=$ Firm size affects the profit sharing of mudharabah deposits

\subsection{Methodology}

In this study the type of research used is causal research which explains the effect of an independent variable on the dependent variable. The independent variables in this study include Return On Assets (ROA), the Cost-Revenue Ratio (BOPO), Capital Adequancy Ratio (CAR) and Firm Size while the dependent variable is the Level of Profit Sharing for Mudharabah Deposits. In this study the data used is secondary data originating from the website www.bi.go.id (13) and the official website of the Indonesia Stock Exchange www.idx.co.id (14).

The population in this study were all Islamic General Banks in Indonesia based on Islamic Banking Statistics data from 2012 to 2017. The samples taken in this study used a purposive sampling method. This technique is done by selecting a sample with a specific purpose in accordance with criteria that have been set. The sample criteria defined by the researchers, are as follows table 1:

Operational Definition and Variable Measurement

1. Level of Profit Sharing for Mudharabah Deposits

$\frac{\text { Bonuses and Profit Sharing }}{\text { Daily average balance }} X \frac{\text { A year }(365)}{\text { Days (30) }} X 100 \%$

2. Return On Asset (ROA)

(Net Profit / Total Asset) x 100\%

3. Operational Income Operating Costs (BOPO)

(Operating Costs / Operating Income) x 100\%

4. Capital Adequacy Ratio (CAR)

(Equity / Total ATMR) x 100\%

5. Firm Size 


\section{Ln(total asset)}

In testing the hypothesis proposed in this study. Researcher used multiple linear regression analysis methods because of the relationship between two or more independent variables where the classical assumptions were previously performed (normality, heteroscedasticity, multicollinearity and autocorrelation test) in the first step.

\section{Results and Discussion}

\subsection{Descriptive Statistics}

In the table 2 shows that the number of samples $(\mathrm{N})$ is 54 data with 9 issuers each year from 2012 to 2017. The mean Level of Profit Sharing for Mudharabah Deposits (TBH) is 5.53, which means the Level of Profit Sharing for Mudharabah Deposits is relatively small at 5.53\%. The minimum TBH value is 3.78\% in Bni Syariah Bank in 2017 and a maximum value of $9.14 \%$ at BRI Syariah Bank in 2014. Mean ROA 0.16 means profit generated from assets owned by Islamic general bank is fairly low at $0.16 \%$. The minimum value of Return on Assets (ROA) is $-11.23 \%$, namely at Bank Panin Syariah in 2017 and a maximum value of $2.26 \%$, namely at Bank Mega Syariah in 2012. Mean the Cost-Revenue ratio (BOPO) of 64.97 means that Islamic general banks can minimize the costs incurred for operational activities in the amount of $64.97 \%$. The minimum BOPO value is $30.80 \%$, namely in Bank Panin Syariah in 2012 and the maximum BOPO value of $298.32 \%$ in Bank Jabar Banten Syariah in 2016. Mean Capital Adequacy Ratio (CAR) of 18.3613 means that the capital adequacy owned by Islamic General Banks in absorbing losses and fulfilling the provisions of the minimum Capital Provision Obligation (KPMM) can be said to be very adequate at $18.36 \%$. Minimum CAR value of $11.10 \%$ at Bank Bukopin Syariah in 2013 and maximum value (CAR) of $36.78 \%$ at BCA Syariah Bank in 2016. Mean firm size is 30.15 , which means that the total assets owned by Islamic general Banks are quite large in generating high profits and the bank's ability to operate is getting better. Minimum value of $28.10 \%$ in BCA Syariah Bank in 2012 and maximum value (SIZE) of 32.11\% in Bank Mandiri Syariah in 2017.

In this study, the classical assumption test has been passed, including the normality test shown in table 3, the multicollinearity test shown in table 4, the heteroscedasticity test with the glejser test shown in table 5, the autocorrelation test in table 6 In this study, the classical assumption test has been passed, including the normality test shown in table 3 , the multicollinearity test shown in table 4 , the heteroscedasticity test with the glejser test shown in table 5, the autocorrelation test in table 6.

Furthermore, the coefficient of determinationtest to see how much the variables ROA, BOPO, CAR and Size explain the TBH variable is in table 7, namely the adjusted $\mathrm{R}$ square of $13.8 \%$. To test the model ( $\mathrm{F}$ test) can be seen in table 8 , which indicates that the research model is feasible because it has a significant effect of 0.023 .

Based on Table 9 Test Results Statistics t each independent variable on the dependent variable can be explained as follows:

1. Variable ROA has a t-count value of 0.395 and a sig value of $0.694>0.05$. This shows that the ROA variable has a positive and insignificant influence. In making the 
hypothesis, H1 is rejected, which means that Return on assets does not affect the level of profit sharing of mudharabah deposits.

2. The BOPO variable has a $t$ value of -1.548 and a sig value of $0.128>0.05$. This shows that the BOPO variable has a negative and insignificant influence. In making a hypothesis, H2 is rejected, which means that BOPO does not affect the Level of Mudharabah Deposits.

3. CAR variable has a t value of $-2,598$ and sig value $0,012<0.05$. This shows that the variable Capital Adequacy Ratio (CAR) has a negative and significant effect. In making a hypothesis, H3 is accepted, which means that the Capital Adequacy Ratio affects the Level of Mudharabah Deposits.

4. Variable Size has a value that has a t value of -2.908 and a sig value of $0.005<0.05$. This shows that the Size variable has a negative and significant effect. In making hypotheses, H4 is accepted which means that Size affects the Level of Mudharabah Deposits.

\subsection{Discussion}

1. Effect of Return on Assets (ROA) on the Level of Profit Sharing of Mudharabah Deposits

Based on the results of the research in testing the hypothesis, Return on Assets (ROA) partially does not affect the profit sharing rate of Mudharabah deposits. This is consistent with the research conducted by Rahmawati (2015) which states that ROA does not affect the profit sharing rate of mudharabah deposits on Islamic Commercial Bank registered with Bank Indonesia. However, the results of this study contradict the research conducted by Umiyati and Shella; Harfiah et al (2016) which stated that Return on Assets (ROA) partially had a significant effect on the Level of Profit Sharing of Mudharabah Deposits on Islamic General Banks in Indonesia. In the Islamic General Bank Revenue Agency Theory (mudharib) which is distributed to the owner of the fund (Shahibul Maal) as the third party's right to profit sharing temporary syirkah funds is a manifestation of bank management's accountability to the fund owner (Shahibul Maal). Islamic General Banks (mudharib) have not been able to maximize the fund managers invested by the fund owners (Shahibul Maal). This is due to an increase in loss reserves in non-performing financing which has resulted in relatively small profits owned by Islamic General Banks.

2. Effect of the Cost-RevenueRatio (BOPO) on the Level of Profit Sharing of Mudharabah Deposits

BOPO partially does not affect the profit sharing rate of Mudharabah deposits. This is consistent with the research conducted by Agus (2014) which states that BOPO does not affect the level of profit sharing of mudharabah deposits. However, the results of this study contradict the research conducted by Laila et al. Harfiah et al (2016) which states that BOPO has a significant positive effect on mudharabah profit sharing deposits. In the Sharia General Bank Agency Theory (mudharib) has not been able to minimize the operational burden, this is because in 2016-2017 the operating expenses have increased due to pressure from the Allowance for Impairment Losses which has affected operational efficiency.

The negative direction between BOPO and beta profit sharing means that the more efficient the operation of Islamic General Banks (mudharib) does not affect the level 
of profit sharing of Mudharabah Deposits. These results are not in accordance with the theory which states that the more efficient the operation of Islamic General Banks in gaining profit / profit, the higher the income of Islamic General Banks and the level of profit sharing to customers will also increase.

3. Effect of Capital Adequacy Ratio (CAR) on the Level of Profit Sharing of Mudharabah Deposits

Based on the results of the research in statistical testing for the independent variable Capital Adequacy Ratio (CAR), partially has an influence on the level of profit sharing of Mudharabah deposits. This result is consistent with the research conducted by Umiyati \& Shella (2016) which states that Capital Adequacy Ratio (CAR) partially influences the level of profit sharing of mudharabah deposits. In the Theory of Islamic General Bank Agency (mudharib) is responsible for maintaining capital and controlling the risks that arise. The capital adequacy owned by the Islamic General Bank in absorbing losses and fulfilling the provisions of the Obligation to Provision of the minimum capital applicable can be said to be very adequate. This shows that the higher the level of capital, the more funding that will be given to mudharib / customers and the profit sharing in the distribution of funds will increase.

4. Effect of Firm Size on the Level of Profit Sharing for Mudharabah Deposits

Based on the results of the research in statistical testing for Size control variables, partially has an influence on the level of profit sharing of Mudharabah deposits. Based on the agency theory of firm size which is seen from the size of the total assets can lead to trust in the Islamic General Bank to be able to manage funds owned by the fund owner (Shahibul Maal). The results of this study are in line with Research Andriyanti \& Wasilah (2010), Anisah et al. (2013) and Setyawati, et al (2016) say that bank size has a significant positive effect on mudharabah savings in Islamic banks in Indonesia. Firm size is the amount of assets owned by the bank and has the ability to generate large profits. The larger the size of the company, the society will tend to save money in the bank because they feel safe and get higher profit sharing. The negative direction between Size and beta for results means that the larger the size of the firm the smaller the level of profit sharing that will be distributed. This can occur when the size of the firm has an effect that there is a high need for funds in the company.

\section{Conclusion}

1. Return on Assets (ROA) does not affect the profit sharing rate of Mudharabah deposits. This is because the increase in loss reserves in non-performing financing has resulted in relatively small profits owned by Islamic commercial banks.

2. The Cost-Revenue Ratio (BOPO) does not affect the profit sharing rate of Mudharabah deposits. This is because the operational costs of Islamic General Banks have increased due to pressure from the Reserve for Impairment Losses which has affected operational efficiency.

3. Capital Adequacy Ratio (CAR) has an influence on the level of profit sharing of Mudharabah deposits in a negative direction. This is because the capital adequacy owned by the Islamic General Bank in absorbing losses and fulfilling the provisions of the minimum Capital Provision Obligation can be said to be very adequate. 
4. Firm Size has an influence on the level of profit sharing of Mudharabah deposits in a negative direction. meaning that the larger the size of the company the smaller the profit share will be distributed. This can occur when firm size has an effect that there is a high need for funds in the company.

\section{References}

1. Saddiyah S. Perbankan Syariah. Retrieved from https://www.kompasiana.com/halimatussadiah31212/5bd4479543322f22f76c96b3/per bankan-syariah. 2018.

2. https://www.ojk.go.id/id/kanal/syariah/berita-dankegiatan/publikasi/Pages/RoadmapPengembangan-Keuangan-Syariah-Indonesia-2017-2019.aspx.

3. Akbar T. The Impact of Risk Profile, Capital Adequacy Ratio And Good Corporate Governance Implementation On Islamic Bank Financial Performance. Res J Financ Account. 2018;9(12):127-35.

4. Sunaryo K. Analisis Pengaruh Return on Asset, BOPO, dan Suku Bunga terhadap Tingkat Bagi Hasil Deposito Mudharabah pada Bank Umum Syariah. Ekon dan Bisnis. 2012;11(1).

5. Rahmawaty R, Yudina TA. Pengaruh Return On Asset (ROA) dan Financing To Deposit Ratio (FDR) terhadap Tingkat Bagi Hasil Deposito Mudharabah pada Bank Umum Syariah. J Din Akunt dan Bisnis. 2015;2(1):92-103.

6. Novianti N, Badina T, Erlangg A. Analisis Pengaruh Return on Asset (ROA), Biaya Operasional Terhadap Pendapatan Operasional (BOPO), Suku Bunga, Financing to Deposits Ratio (FDR) dan Non Performing Financing (NPF) Terhadap Tingkat Bagi Hasil Deposito Mudharabah (Studi Empiris pada Bank Um. J Bisnis dan Manaj. 2015;5(1).

7. Rahayu S. Pengaruh return on asset, BOPO, suku bunga dan capital adequacy ratio terhadap tingkat bagi hasil deposito mudharabah pada perbankan Syariah. J Account. 2015;1(1).

8. Zinman J, Karlan D, Young J, West A, Weill L, Godlewski CJ, et al. Observing Unobservables: Identifying Information Asymmetries With a Consumer Credit Field Experiment. Econometrica [Internet]. 2009;4(3):1993-2008. Available from: http://www.eurojournals.com/MEFE.htm\%0Ahttp://www.jstor.org/stable/1879431\%0 Ahttp://about.jstor.org/terms\%0Ahttp://link.springer.com/chapter/10.1007/978-1-34924002-

9_9\%5Cnhttp://qje.oxfordjournals.org/lookup/doi/10.2307/1879431\%0Ahttp://www.c rimbbd.org/W

9. WIRAWAN A. PENGARUH ROA, ROE, DAN BOPO TERHADAP TINGKAT BAGI HASIL DEPOSITO MUDHARABAH PADA BANK UMUM SYARIAH. STIE PERBANAS SURABAYA. 2016;

10. Usanti, Shomad. Hukum Perbankan. Jakarta: Kencana. 2016.

11. Umiyati U, Syarif hella M. Kinerja Keuangan dan Tingkat Bagi Hasil Deposito Mudharabah Pada Bank Umum Syariah di Indonesia. urnal Akunt dan Keuang Islam. 2016;4(1):44-6.

12. Fraenkel JR, Wallen NE, Hyun HH. How to design and evaluate research in 
education. New York McGraw-Hill Humanit Sci. 2011;

13. www.bi.go.id.

14. www.idx.co.id. 